\title{
2
}

\section{Horseracing, the media and British leisure culture, 1918-39}

M edia experience was part of everyday activity. It helped make sense of the world and construct cultural citizenship. ${ }^{1}$ Reading the racing pages in the sporting, national and regional press or the adverts, novels and non-fiction with a racing theme, provided a temporary escape from Britain's economic problems. Watching breathtaking racing action shots in newsreel and film was enhanced by ever-improving photographic equipment. As electricity and radio became more available, the $\mathrm{BBC}$ radio commentaries on the premier races, with their sustained dramatic action, contributed to the creation of an emerging mass culture. In the late 1930s the first television coverage arrived.

The inter-relationships between racing and British culture, society and the media were ambiguous, complicated and subtle. The following sections explore the highly complex, sophisticated and resolutely populist cultural representations of racing and betting in the mass media, whose ideological power and dominant, negotiated and oppositional influences played a crucial role in fostering British sporting identity. ${ }^{2}$ They fed off and contributed to an interest in racing, helping to reconstruct social identities and rework norms and values. The media confirmed and reinforced the extent to which racing was part of a common culture, a highly popular leisure form across all levels of British society, and made celebrities out of leading racing figures.

Racing and the media were interdependent, shaping and reflecting the increased interest in racing and betting, whilst at the same time, in fiction and film, presenting a partial, distorted or imagined view of racing culture. Ever more people bought the leading newspapers with their racing pages, watched the last furlong of major race meetings in the cinema, or listened to radio commentaries, perhaps after purchasing sweepstakes or placing a bet. Interest in and support for racing became more widely acceptable, even amongst the middle classes. This contributed to wider changes in social attitudes to betting. Some 
older racing journalists were less enamoured of such increased attention. J. B. Booth, for example, felt in 1938 that 'modern race reporting has been reduced to an exact science, and like most exact sciences ... it is a colourless affair'. ${ }^{3}$

\section{Media coverage of racing}

Sports journalism played a key role in the wider construction of racing ideology, and located it within wider structural and ideological constraints. ${ }^{4}$ For racing insiders and regular punters, detailed racing coverage was found in the specialist racing press. Its writers provided informative, forward-looking and vital data on horses' form, weight carried, jockey, place on the start and similar material, for an audience who needed that knowledge and information for a range of purposes. The tone of such publications was one of camaraderie, implying that the reader, like the writer, was an integral part of British racing. The material appealed most to those who believed in the rationality of betting. But owners could read an expert's opinion about their horse, breeders could enjoy the coverage of stud farms and see how other stud farms were doing, trainers could keep an eye on the progress of two-year-olds at other stables, to help future placing of horses, and bloodstock agents could read detailed reports from overseas correspondents. Pictures could be cut out to decorate the training stable saddle room. Thus different sections might be read by owners, breeders, stable lads, jockeys and trainers.

Journalistic autobiographies show that many built a career in racing. ' 'Warren Hill' of Sporting Life had been in racing for over fifty years when he retired. ${ }^{6}$ Journalists had their own organisation, the Racecourse Press Committee. Messrs Weatherby issued about 120 press passes each year. There was a clear hierarchy of status and income, with ability plus the patronage and recommendations of older journalists seen as helpful in building careers. When Norman Pegg (Gimcrack) first entered the racing press he had found it unwelcoming, 'a snooty closed shop', with many poorly paid, earning a precarious living. ${ }^{7}$ This changed with growing public interest in racing. Newspapers increasingly wanted a new, well-informed, more journalistic approach, with writers able to tip occasional winners but also to recognise 'stories' and 'news values'. Quintin Gilbey's jobs for the Evening Standard and Daily Sketch in the 1930s required him to write a diary during big race days, and a short daily article dealing with personalities. ${ }^{8}$ The proportion of better-educated, sometimes ex-public-school, professionally literate writers grew, enjoying a regular racing round of contacts, congenial company and pleasant working conditions. Meyrick Good suggested that many had come 
from the universities. ${ }^{9}$ Others were ex-army officers. To develop good relationships, they had to be convivial, highly-skilled socially, with appropriate manners. Geoffrey Hamlyn, for example, was always 'polite, courteous ... one of nature's gentlemen' ${ }^{10}$ Around 1920 most received minimum starting salaries of 8 guineas a week plus first-class expenses, while leading reporters earned annual salaries of around $£ 1,000$. The top jobs, like that of 'Ajax' (Jimmy Park) of the Evening Standard, were soon carrying a salary of from $£ 1,250$ to $£ 2,000$ per annum, with 'an adequate expenses allowance. ${ }^{11}$

The Sporting Life was the widest-circulating London racing newspaper, selling some 100,000 daily $2 d$ copies in 1926, providing detailed betting news, 'form-at-a-glance' of previous races, and even details of silks for feature races. Within racing, some of the elite, like trainer the Hon. George Lambton, dismissed it as 'a paper of no account', one 'looked on with contempt by all racing people'. ${ }^{12}$ Others read it avidly. It employed specialised touts who acquired information by talking to stable boys, or observing horses in training, so stable secrets were difficult to keep. Copies of the paper could be found anywhere people gathered: in barbers' shops, in public houses or at the workplace, and it also provided information on theatres, tennis and golf, and stallions at stud, all suggesting a substantial upper- and middle-class readership. Some public libraries stocked it and at least one public school, Charterhouse, carried a copy in the school library. ${ }^{13}$ At Dean Close school, Cheltenham, pupils read it. ${ }^{14}$ An annual summary, Ruff's Guide to the Turf, which gave a complete record of all racing under Jockey Club and National Hunt rules, cost $15 s$ in 1921, rising to $30 \sin 1930$.

A similar, but slightly more working-class sporting paper, the Sportsman, covered racing, football, billiards, athletics, rowing, bowls and boxing, but its circulation was falling and it shut in 1924 . The dominant northern daily racing paper was Hulton's Sporting Chronicle, printed in Manchester at 2d, which claimed to provide 'the Best and Latest STABLE Information'. With the Sporting Life it provided official starting prices. ${ }^{15}$ It covered football, cricket, dog racing and other sports, but concentrated on racing.

Before the First World War few daily papers, beyond the Daily Telegraph and Morning Post, had their own racing representative. Instead the Press Association had supplied a service of racing news to newspapers. The popular press of the interwar years opened up racing and its affairs to wider public view and understanding, hugely increasing and sensationalising its coverage, a point already alarming anti-betting campaigners in $1923 .{ }^{16}$ Each paper had tipsters, providing further betting information and a new lighter touch of incidents, gossip 
and 'talking points' for the ordinary reader. Despite its Liberal political slant the News Chronicle was the first morning newspaper to provide a list of probable starters and jockeys. Others soon followed. Even The Times used bolder, larger and more eye-catching headlines in its racing reports, an indication of racing interest amongst its more select, well-educated readership. Racing's international links were catered for by Reuters, who now provided reports and results for the major races on the Continent, Australia and elsewhere.

Racing journalists employed specialist language, written for the supposed racing insider, replete with fairly obscure terms. 'Busy', for example, could mean known to be out to win and expected to do so. 'Ran loose' meant a horse unbacked by its stable. A 'stumer', 'dead meat', a horse not 'trying' or 'pulled' in some way, all suggested a horse not intended by jockey, trainer or owner to win. Racing journalists had an ambiguous relationship with racing, fairly detached, but, as journalist reminiscences show, with a strong sense of group cohesion. They spent much time away from home, and needed to create mutual support systems. As racing insiders, they were always very generous with praise, and avoided direct censure of jockeys, trainers, horses or the Jockey Club or NHC, although betting and bookmakers might come under fire. The obituary of Henry Dixon, one of the best-known journalists on the Sportsman, noted his 'smooth and efficient style' and how 'he always tried to avoid hurting anyone's feelings' ${ }^{17}$ Of Quintin Gilbey, the jockey Gordon Richards said 'nothing gave him more pleasure than to write a glowing report' ${ }^{18}$ Such behaviour paid off. They were generally trusted, respected and well liked.

Newspapers printed photographs of racing even before the First World War, but after it there were great improvements in the efficiency and quality of photographic reproduction, alongside new technologies of layout and design. This visual reorientation of the press helped increase circulation and define style and journalistic personality. The cinema created a demand from those wanting to see racing as well as read about it. ${ }^{19}$ Papers maximised their audience by increasingly collapsing cultural distances, trying to get consumers to identify with the paper's production team, and rapidly replicating and distributing racing material in ways that brought Ascot to Airdrie, Newmarket to Newcastle and vice versa. The Daily Mirror's expansion of racing coverage helped it become the largest daily tabloid newspaper in the 1930s. Its presentation was highly visual, focusing on racing individuals as much as on racing itself. The Daily Telegraph, aiming determinedly at a middle-class readership, had far more racing pictures than before the war. The nature of photographic images newspapers chose varied depending on core readership. In 1927 The Times provided occasional, 
usually staid racing photographs with an elite view of racing: London-based, or from those meetings for which 'society' might organise a visit or houseparty, together with pictures of horses from high-status studs, such as those of Lord Glanley or Lord Derby. By 1937 The Times, although still a 'class' as opposed to a mass paper, had almost as much on racing as the Daily Mail.

For major races most national papers included a rich mixture of discursive features, detailed race coverage, betting, winner's pedigree and human-interest stories, by their 'Special Correspondent' and 'Own Correspondent', writing in the first person. Reports and tips from such specialist turf writers had turned them into well-known and widely-read figures, although writing still under short, easily memorable noms de plume - 'Bouverie' in the Mirror, 'Hotspur' in the Telegraph, the 'Scout' in the Daily Express, 'Robin Goodfellow' in the Daily Mail, 'Carlton' in the Daily Dispatch, 'Gimcrack' in the Daily Sketch. ${ }^{20}$ Even the Labour Daily Herald had a racing section, and the Communist Daily Worker reluctantly included starting-price odds and tips. That papers provided tips across the spectrum of class and politics, illustrated the extent to which the commercial press met a clear demand for racing news.

The cult of expertise had its parallel in racing and the papers fostered this, although only their experts' triumphs and not their failures were trumpeted. Although headlines were still dominated by the name of the winning horse, coverage of major races included sensationalist presentation, human-interest accounts, and interviews with jockeys, trainers and owners before and after important races. The racing journalists were themselves part of the racing world, and the register in which they addressed their readers often showed an assumption that they too were friends, close acquaintances, part of that same world. They were rarely overtly critical. If reviewing runners, something positive would be found about almost every horse. Any controversy, problem or difficulty would be focused on the horses, who were found plausible excuses for failure, such as too heavy or too hard going, or too much or too little racing. Any overt blame for jockeys or trainers was extremely rare, and comments were always guarded. More likely, a trainer would be described as in or out of form, suggesting a large measure of luck. Personal biographies suggest that journalists were largely friendly and positive, and had substantial elements of mutual solidarity.

Local and regional morning and evening papers also covered racing in some detail, with only rare exceptions such as the Manchester Guardian which were sufficiently anti-betting to forgo the extra sales that racing information generated. Most morning papers gave lists of expected runners and reports of the previous day's racing, and provided some sort of tipping service; evening papers 
gave racing results. Any local race-meeting would be given a fuller, more detailed report. In areas where betting was particularly popular, papers such as Liverpool's Sporting Echo or Sporting Express often had a separate racing-sheet edition of two or more pages. These were first published before mid-day with lists of runners, summaries of tips from the morning papers, reports from the various training grounds, and general racing news, and were followed up by later results editions. In London similar papers like the Star or London Evening News supplied a large public demand. ${ }^{21}$

The sporting press, national and leading regional newspapers almost all expected their racing columnists to provide tips about potentially winning bets. Although most betting readers took these with a pinch of salt, they provided an extra source of advice. Some readers would have been aware that leading national tipsters' success was highly variable. The Sporting Chronicle, for example, ran a Challenge Cup for tipsters, and its data showed clearly that over a season only a small proportion of tipsters showed a profit if all their tips were backed with a consistent sum. ${ }^{22}$

Table 2. I Turf correspondents showing profit on a season, |929-3|

\begin{tabular}{cccc}
\hline Year & $\begin{array}{c}\text { Total number of } \\
\text { correspondents }\end{array}$ & $\begin{array}{c}\text { Number showing } \\
\text { profit }\end{array}$ & $\begin{array}{c}\text { Percentage in } \\
\text { profit }\end{array}$ \\
\hline 1929 & 36 & 12 & 33.3 \\
1930 & 35 & 6 & 17.1 \\
1931 & 43 & 3 & 6.7 \\
\hline
\end{tabular}

Source: Sporting Chronicle

The frequency of appearance of jockeys' comments in the daily press demonstrates the extent to which these sporting celebrities were of interest to readers. This coverage, together with rarer interviews for the cinema newsreels or wireless, helped to promote the top jockeys even more. Their views on racing prospects were regularly reported and approvingly received. The memoirs of the much-loved jockey Steve Donoghue were serialised in the Sunday Express in 1923. In 1927 the London Midday Standard, which had contracted Donoghue to write for them, arranged for a fleet of Tiger Moths to fly over London and by means of a series of lights give out his coded 'tip' for the Derby to its readers. ${ }^{23}$ The race for the jockey championship was also an appealing feature. Top jockeys became celebrities, gossipy coverage of their social appear- 
ances at nightclubs, banquets and other fashionable gatherings now aiding press circulation. The racing industry itself increasingly used jockeys' fame to foster its links with the wider community through specially organised London charity events: annual dinners, cricket matches between the sporting press and jockeys, or football matches between boxers and jockeys. These were mirrored in the provinces, adding to both the work and the pleasure of racing men. In York, for example, in 1932 charity events for the funds of the local hospital included a football match between jockeys representing the North and the South and a recently-initiated (1931) charity golf tournament open to owners, trainers, jockeys, bookmakers and the sporting press. The press also publicised the jockeys' attendance at the York Charity Dance at the Assembly Rooms, where Donoghue presented the prizes. ${ }^{24}$

Ancillary events connected with racing were also well covered. For example, when in 1923 the journalist and crime writer Edgar Wallace became president of the Press Club, he instituted the Derby Dinner, to which top owners, jockeys and trainers were invited on the Monday before the race. This soon became an established and well-reported sporting occasion, the press praising itself. Wallace continued to preside at the lunch, giving the introductory speech with humour, imagination, reflection and sentiment until his death. In contrast, the Grand National Party at the Adelphi Hotel after the race, was well-known as a raucous, uninhibited heavy-drinking celebration characterised by excess behaviour and the occasional fight. ${ }^{25}$

Press portrayal of women's racing involvement expanded. There was recognition that some women liked to bet. More commonly, papers at all levels flattered women readers and boosted their self-esteem by allowing them to participate vicariously in the fashion dilemmas and choices of the upper classes attending the racing at Ascot, Goodwood and other society events. National papers almost all featured occasional racing fashion columns focusing on what the 'top people' were wearing, with titles like 'Dresses at the Oaks: the Royal Party', or 'Gold Cup Day: Ascot Frocks and Colours' ${ }^{26}$ Towards Ascot, the high spot for feminine fashion in the Royal Enclosure, these reports were reflected in London with displays of 'Ascot dresses' in dress shops and costumiers aimed at building up female demand. There were similar features in the provinces, such as the York Herald's column 'A Woman Goes to the Races', which covered in some detail the 'dresses and suits seen on the Knavesmire' or the Liverpool Echo's 'Tweed the Favourite at Aintree: Fashion Today at the Races', suggesting that there was a female interest group more interested in haute couture than horses. ${ }^{27}$ Public interest in the doings of the wealthy was also reflected in the long lists of 
aristocratic and gentry guests at racing country houseparties. Such material located racing as part of cultural baggage for the socially aspirant.

For the betting aficionado, weekly and annual material was also available. The Chronicle's hugely detailed form guides were popular - especially the bulky weekly Saturday Up-to-Date Form Book available on Fridays for weekend perusal. Its annual versions of Raceform and Chaseform covered flat and National Hunt racing respectively, while its annual Racing $U_{p}$-to-Date at $3 s$ was a cheaper version of Ruff's Guide. Less popular, but also available in the 1930s, were the News Chronicle Racing Annual and Cope's Racing Encyclopedia, first published in 1939, for those who were keen without being technically expert. Such summaries provided a compendium of comprehensive, informative and useful racing data and advice, with horses to follow, a basis for analysis and discussion throughout the year. Further books provided useful data on sprint times for two-year-old racing. The sheer number of such publications demonstrates the powerful hold of betting.

Racing also had a broader factual literature. An indication of where racing representations stood in relation to other fields of sporting literature can be found by comparing the number of books acquired by the British Museum on different sports in particular years. Between 1931 and 1935, for example, golf topped the list with eighty-nine books, many being short club handbooks. Angling, perhaps an even more popular participant sport of the period, had seventy-nine, and cricket sixty-two books. Although there were only twenty-five in the racing section, there were as many again relating to betting on racing, and further books on training and riding thoroughbreds. Overall the number of racing books listed was only slightly less than those devoted to cricket, and far more than association football's sixteen books or rugby's nine.

Their style reflected a clear demand for racing information from a more literate middle- and upper-class, and generally older, readership. Literary and subhistoricist approaches pre-dominated. Content was upper-class, romantic and anti-urban in tone, with a highly ambiguous attitude to mass betting, commercialism, course criminality and changing forms of social relationships in its interpretative structure. The writings of Jack Fairfax-Blakeborough perhaps most typified this style. Unlike the moral rhetoric of cricket which was emblematic of honesty, selflessness and upright conduct, his work carried more mixed messages. His Analysis of the Turf (1929) looked at 'owners, trainers, jockeys and race officials, with the respective part each plays' and the 'difficulties with which each has to contend'. It claimed that 'sportsmen in the very best and truest sense of the word' followed racing, yet acknowledged its 'supposed rascality', its 'turf 
rogues and roguery', and 'turf flotsam and jetsam', accepting their existence but minimising their extent. His books coupled an affectionate and nostalgic view of racing's past and fears for the future of rural landowners with a more cautious admiration for the efficiency and innovation of a few racecourse managers. ${ }^{28}$ Blakeborough published some 112 racing books, many on the history of northern English racing, alongside short stories, plays and newspaper columns. $^{29}$

A similarly defensively nostalgic view pervades much other published material. The London publishers Hutchinson and Co. were major publishers of racing memories, in which there was significant interest amongst middle- and upper-class readers. Amongst many other books they produced Charles Morton's My Sixty Years on the Turf (1930), Sidney Galtry's Memoirs of a Racing Journalist (1934), Arthur Sarl's Horses, Jockeys and Crooks: Reminiscences of Thirty Years' Racing (1935) and Quintin Gilbey's Racing for Fun (1936). Racing memoirs produced by other publishers included C. A. Dighton, My Sporting Life (Richards, 1934). Another literary non-fiction form was the biography or autobiography in which the lives of trainers, owners, jockeys or even horses generally received fairly adulatory, non-critical treatment, unsullied by mention of dishonesty or unsporting practice. ${ }^{30}$ Racing history texts centred on the racing elite, with histories of 'major' individuals ${ }^{31}$ and 'key' races ${ }^{32}$ alongside general treatments. ${ }^{33}$

Listeners hoping to hear racing on the wireless were initially disappointed. The BBC, with its dedication to the raising of public taste, at first showed little interest. It only reluctantly broadcast the Epsom Derby result in $1922 .{ }^{34}$ It began presenting studio sport in 1923 but maintained an ambivalent attitude towards mentioning racing results. It wished to promote 'correct' social attitudes and enhance its own respectability, and had moral reservations about gambling. It was also concerned about harming the press, since the 1923 Sykes Committee had reported to Parliament that broadcasting racing results would damage newspaper sales. In 1925, the year when the Kentucky Derby was first broadcast in the USA, there were negotiations about broadcasting a 'sound impression' (without commentary) of the Epsom Derby but these came to nothing, partly due to heated press opposition. ${ }^{35}$ In 1926 the BBC finally introduced the 'daring experiment' of a Derby outside broadcast to 2LO London listeners. It was not a great critical success. The inexperienced commentators were poor, ending the brief broadcast with a very tentative announcement of the result, 'It looks like 9-5-1', rather than providing the horses' names. ${ }^{36}$ The BBC first provided commentary on the Grand National in March 1927. This was 
taken more seriously, and broadcast on the London and Daventry transmitters. The BBC described it as 'a new and thrilling kind of broadcasting entertainment'. It was the first suggestion of a slightly more popular flavour being given to sport, and a clear recognition of racing's cultural importance. The broadcast lasted over an hour and used five microphones, two of which picked up background noise from the crowd, betting ring and unsaddling enclosure, helping to create atmosphere, as did crowd interviews. Meyrick Good, a well-known racing journalist and expert race reader, provided commentary. His assistant, George Allison, an Arsenal director and future manager, already commentated regularly on amateur and professional football, using a slightly more excited and less detached style of commentary. ${ }^{37}$ Good had 'read' the race to George V since 1921 , and on this occasion the king stood to Good's right by the open microphone, with Allison providing the 'colour'. ${ }^{38}$ Good got over-excited and omitted details of the official placings.

By then an emerging part of the BBC's mission was to cover 'national' sporting events, accommodating quietly to a more genuine national sporting culture and providing a shared frame of reference across widely divergent groups. Both the Grand National and the Derby were always covered thereafter, consolidating them as key features of the national sporting calendar. They became part of an annual core of broadcast national rituals and ceremonies, like the Boat Race, Test Matches or the king's Christmas message. This helped to present the BBC in a more democratic and less elitist light, while conferring increased respectability and status on racing. The two races were the leading betting races of the year. Now even those who never attended a race meeting and had little interest in racing were made familiar with them. Listening audiences were large, and coverage may well have helped to further expand betting on the two events or participation in workplace sweeps. Racing was becoming basic British cultural capital, something almost everyone could anticipate, recognise and respond to. It also spread an image of British culture abroad. The 1933 Derby commentary was relayed to India, Canada, the United States and Ireland. ${ }^{39}$

Technological changes improved the presentation. For the 1927 St Leger, the 'desensitised' microphone that cut out background noise on the commentary was used for the first time. This allowed the use of a separate microphone for atmosphere, the sound level from which could be controlled by an engineer. In 1928 the length of broadcasts was shortened to half an hour, and the approach was tightened up. The broadcasts had some limited negative impact on evening newspaper sales but made the major races ever more popular, attracting excellent listening figures from the early 1930s. The enclosure of 
courses in the nineteenth century had reduced racecourse attendance, making spectators predominantly adult males, removing racing from the experience of many women and children. The new BBC sports coverage, coupled with the increased popularity of sweeps on the Derby and National, was therefore important in widening access to racing and disseminating interest in its major events on a new and larger scale.

'Mains' valve sets with attached loudspeaker became a common feature in the early 1930s. Hire purchase spread, and radios became smaller and more compact. In 1937 over eight million licences were paid for, and by 193971 per cent of all households had a radio, allowing ever more people to experience the entertainment and excitement of racing. Further technical improvements were introduced to outside broadcasting in the 1930s, and by the later 1930s more races, including the Chester Cup, the Oaks, the Cesarewitch, the Eclipse Stakes and the Ascot Gold Cup, were being broadcast. The latter incorporated yet another innovation, a description of women's fashion in the enclosure, by a female broadcaster. To maintain standards, Quintin Gilbey, who had appeared in a divorce case, was formally refused entrance to the Royal Enclosure as a commentator, but was allowed in after being given a footman's uniform, which satisfied all parties! $!^{40}$ Some of the regions began providing race commentaries too.

In the 1920s the BBC had found that racing experts often made poor broadcasters, while those with good microphone technique were generally unable both to 'read' a race and share the information about owners, jockeys, trainers or chances which many listeners wanted. By the later 1930s, however, the BBC had developed the technique of having an expert 'race reader' coupled with a 'microphone speaker', a professional BBC staffer. New commentators like Thomas Wood and Richard North were now more able to provide what the public wanted in terms of race reading and description. The 'reader' gave guidance to the commentator, whose voice was the only one heard, thanks to the desensitised microphone. The scene was now better set, the course and horses were better described, and the pace and pitch of delivery began to match the crowd noise.

Even so, commentating was still difficult. Given the often inconvenient vantage points, accurate interpretations of the race were difficult to achieve, especially in a close finish. At Aintree in 1938, the commentary on the Grand National 'left millions of listeners to the broadcast description of the race uncertain who had won' for just this reason. ${ }^{41}$ During the race more information was given about those horses most favoured in the betting market, although the BBC still expressly forbade reference to betting. The starting prices of the 
winner and placed horses were never given until well after the Second World War. The BBC also gave far less coverage to top jockeys than the press, although when Gordon Richards achieved a record 247 wins in a season in 1933 he made a nervous broadcast from Liverpool's Adelphi Hotel. Steve Donoghue only made his first broadcast in 1935 when he appeared with Noël Coward on Henry Hall's guest night. ${ }^{42}$

The first television outside broadcasting of the Derby was carried out as early as 1931 by the Baird Television Company in cooperation with the BBC, and a lucky few watched it at home in London on primitive 'Televisors'. The Bloodstock Breeders' Review was awed. 'Truly,' it admitted, 'we are living in an age of wonders.' 43 Baird claimed that it 'marks the entry of television into the outdoor field and should be the prelude to televising outdoor topical events', but the $\mathrm{BBC}$ initially failed to follow it up. ${ }^{44} \mathrm{~A}$ more serious attempt was made in the late 1930s, when the BBC began to develop television coverage in the London region for those few richer homes where a set could be afforded. Outside broadcasts of the Boat Race and Wimbledon were attempted. The BBC considered coverage of the 1938 Epsom Derby, a recognition of the attraction of the event to this wealthier market, and approached the local authority for van space in early January. Before even being approached, the Epsom Grandstand Committee, echoing the opposition of the traditionalist Jockey Club, and perhaps feeling it would cut attendances, issued a press statement, saying that they would 'not in any circumstances give their permission'. ${ }^{45}$ As a result the BBC was approached by Leonard Jayne of the Pony Turf Club, offering their 1938 Pony Derby as an alternative, an offer accepted by the BBC, who recruited Jayne as race reader and broadcaster. ${ }^{46}$ This forced a rapid change of heart by the Epsom Committee, and both Derbies were shown.

At Epsom two commercial companies used the television transmission 'live' as a commercial 'trailer' for potentially marketing the transmission in cinemas and elsewhere. There was a private showing by Gaumont British at the Tatler News Theatre in London on an 8-foot-square screen. Reportedly the crowd there found it 'as thrilling as being in the grandstand', and could not refrain from bursting into applause during the close finish. The TV presentation tried to create a 'realistic' atmosphere, showing the fun-fair in the valley, the rows of bookmakers, and the king and queen returning from the paddock after inspecting the horses. ${ }^{47}$ It was also shown by the Scophony Company to six hundred people at a Kennington department store using a 6-foot screen. ${ }^{48}$

The press coverage of the dispute, good weather and the TV cameras brought large crowds to Northolt for the Pony Derby for the second horserace 
to be televised in Britain. The entertainer George Robey was introduced to viewers, Freddy Grisewood provided context, and the commentary was given by the official Northolt commentator, Leonard Jayne, perched on the roof of the Tote Stand.

Despite their technical imperfections and limited visibility at Epsom, partly thanks to rain, the broadcasts generated widespread interest and increased audience, resulting in further television coverage of the Derby in 1939. But racing was conservative, and only a minority of racing executives around London welcomed the new medium. When in the same year the BBC approached Sandown Park with a view to producing a commentary on the July Eclipse Stakes, it was turned down. ${ }^{49}$ The popularity of TV racing was still well in the future.

The audience for these early television broadcasts was small. By contrast the cinema, the most dominant cultural leisure form of the period, and deeply rooted in the British social fabric, played an especially significant role in helping to stimulate and sustain interest in racing. Going to the cinema was a potent medium of popular cultural practice, providing a powerful illusion of simultaneity, truth and participation, and both confirming and transcending that world. Sport was already a pervasive popular feature of news reporting in cinemas. Indeed, a film of the Epsom Derby had been shown at the Alhambra Theatre, amidst 'wild enthusiasm', as early as $1896 .^{50}$ Pathe Gazette and News sports features helped to alter ordinary people's views of sport. Fights by top boxers such as Carpentier, Tunney or Dempsey were regularly shown, as were major national sporting events such as the Football Association Cup Final. By 1921 Gaumont Graphic's film of the Derby was quite technically sophisticated, and a hundred or more copies were sent out the same evening. ${ }^{51}$ In 1923, when the British horse Papyrus was sent to Belmont Park course in New York to race the American champion Zev, accompanied by top jockey Steve Donoghue, the visit was recorded by Pathe News. The 'official film' had excellent pictures of the actual race from start to finish, including slow-motion sequences, and pictures of the crowd, as well as glimpses of Papyrus during the journey and of the training quarters where the two horses did their preliminary work. As these new techniques of recording racing were more generally applied to other races, journalists found their eye-witness, rapidly written and more spontaneous reports sometimes at variance with films, forcing more mature reflection. To quote just one example, a radio commentator wrote, 'the motion picture of the Grand National which I saw yesterday has made me revise some of the views I held before'. ${ }^{52}$

Film sound caught the excitements of the course even more. Gaumont Sound News covered the Derby in 1929, the same year that Pathe Sound Magazine was 
introduced. Two American-owned organisations, British Movietone News (1929) and British Paramount News (1931) also began to compete, soon using a modernised magazine format, with a separate sports section. In 1932 the British Movietone Derby introduction included crowds arriving, the horses, the pearly kings and queens, the real king and queen (a neat social contrast), gypsies and stunt men. Its presentation indicated both the liminal and carnivalesque nature of the course, and its underlying boundedness and respectability, reflecting traditional British social values and characteristics. Then the title was introduced and music started as the race began, with some audibility of thudding hooves and distinct crowd dialogue, perhaps dubbed on later, creating excitement. The finish was shown in slow motion. As techniques developed, big race coverage even occasionally included brief interviews with jockeys, owners and (much more rarely) trainers.

Promoters of race-meetings often sold exclusive rights to one company. Pathe, for example, claimed to present 'the only authentic and official pictures' of the 1933 Grand National, which was 'described by Captain G. H. Gilbey, the famous racing journalist'. ${ }^{53}$ It had a staff of twenty-six at the course, but had its work cut out to keep opposition cameras out. The 'cinema battle' was a regular occurrence at Aintree in the 1930s. In 1935 'a large balloon was ready to be floated in front of the lenses of the pirates, and while the race was on bright flares shone over the canal bank, presumably to blind the lenses of others, and a smoke screen was set up'. ${ }^{54}$

\section{Selling products}

Racing was also used as a powerful advertising metaphor. Sporting Lifés advertisements, aimed at upper- and middle-class sporting men, formed a substantial part of the paper. For example, its advertisements during Derby week 1924 included Burberry coats ('a winner all the way'), Austin and Morris cars, car tyres, Schweppes tonic, goldsmiths and silversmiths, makers of racing binoculars, and a number of cigarette firms.

In towns with popular races local advertisers of products with more limited racing connections often used racing in their advertising slogans. There may even have been some external social pressure to do so, a point made explicit in the Liverpool civil, navy and military tailor Albert Henderson's 1922 advertisement, which stated 'somehow it seems customary for the advertisers of Liverpool to get a little topical interest into their advertising during National Week, and to the dictates of this custom we yield'. Other advertisements during 
that week included 'Monserrat: the Grand National Health Salt', and 'The National Favourite: Barker and Dobson Viking Chocolate. ${ }^{55}$ Betting language was often coupled with the name. In York, for example, you could get 'A certainty for the Ebor Day purchaser. When you purchase at Gawthorne's you are on a sure winner. ${ }^{56}$ Cigarette advertising cashed in on the popularity of racing. J. Player and Sons, for example, had annual advertisements during race weeks in local newspapers, showing middle-class or respectable working-class men smoking whilst watching the races, accompanied by slogans like 'It's a Certainty, Players Please' or 'Horses for Courses, Players Please', picking up on the verbal cliches associated with racing and utilising them in a new commercial context.

Cigarette cards were another potent advertising medium. Their sporting coverage was popular, with football, cricket and then racing themes most popular of all. Racehorses and jockeys were the most commonly produced series. In 1933 alone there were three racehorse sets. Player and Sons issued a set of 'Derby and Grand National Winners', while Ogdens and Hignett Bros. had sets of 'Prominent Racehorses'. No one racehorse seems to have caught the public imagination in the way Seabiscuit did in the USA, although Brown Jack, Golden Miller and Papyrus came close. ${ }^{57}$ Series which cover wealthy racehorse owners, like Ogdens' 'Trainers and Owners' Colours', are more from the 1920s, while the 1930s had far more jockey series, such as Gallagher's 'Famous Jockeys'. Richards (thirty-four cards), followed by Donaghue (twenty-six cards), appeared most often.

Racing and betting were also perennial themes for topical popular cartoonists, especially Bill Haselden of the Daily Mirror, Joseph Lee of the London Evening News, David Low of the Evening Standard, George Strube of the Daily Express, and Tom Webster of the Daily Mail. They often used racing as a cartoon metaphor for commenting on current events, especially politics. Cartoons about racing itself also appeared regularly - clear evidence that readers had sufficient background racing understanding to 'read' their visual humour.

Betting facilities also advertised themselves. Bookmakers receive detailed treatment elsewhere, but 'specialist' tipsters advertised too, implying that they had extra, more secret information at a price. Newspaper editors occasionally pointed out that 'any person who could find winners with regularity would keep the knowledge to himself', but kept publishing them. They brought in revenue. ${ }^{58}$ Some cheap newspapers consisted entirely of betting tips, advertising professional tipsters and lucky mascots. ${ }^{59}$ Tipster advertisements in the various Sporting Chronicle publications usually included lists of testimonials from the 
successful - not, naturally, from the unsuccessful. Many adverts offered to send cables to racing fans abroad, which implies that a lucrative and perhaps safer market existed where the unsuccessful had less opportunity of complaint. The 'Newmarket Resident Commissioner' suggested he offered 'a splendid opportunity to South African backers', and testimonials from South Africa were common. Lawson of Southport quoted his 'colonial clients', such as the following from Jamaica, 'Received Cables of 20th October! Had $£ 10$ on LOVER'S FATE Won 100-8 ... Must REALLY CONGRATULATE YOU ... I am including a PRESENT of TEN POUNDS in my draft' ${ }^{60}$ Some tipsters were frauds. Others did their best to provide reliable information, although often gaining it by spying on trials or bribing stable boys in local pubs. One, who had a hotel bill of $£ 50$ a week, claimed an income of up to $£ 2,000$ for a single successful major race, paid for by being 'put on the odds to a fiver' by successful punters. ${ }^{61}$

\section{Fictional portrayals of racing}

Fictional representations of racing, in films, plays and books, were quite common during the period. Racing films were generally positively described in local papers. One 'Grand Holiday Attraction' at West Hartlepool in 1936 was 'a fine racing story which provides some excellent entertainment' ${ }^{62}$ In the $1920 \mathrm{~s}$ most were American, largely reflecting American attitudes. Riders Up (1924) had many of its scenes filmed on an American racecourse, although the later Marlene Dietrich and Robert Donat film Knight without Armour, a good example of the 'Hollywood idea of England' genre, made in England but aimed at the international market, featured a re-enactment of the 1913 Ascot meeting. American films often saw racing as a crooked sport, and many of their plots had some form of racing crime as the main storyline, alongside a romantic subplot. They often assumed that racing attracted criminals who were out to fix races, nobble opponents' horses and run their horses dishonestly, while other owners, especially the hero, were men of integrity: honest and straightforward, never bet and ran their horses straight. British filmgoers preferred more comic American racing films such as the Ritz brothers' 1939 film They're Off. ${ }^{63}$

British-made films are more revealing about British cultural attitudes to racing and betting, and recent research has recognised their importance in British interwar cultural history. ${ }^{64}$ The 1930 s was a prolific period of British film-making, stimulated by the Cinematograph Films Act of 1927, which required a quota of all films shown in Britain to be produced here, rising from 5 
per cent in 1928 to 20 per cent by 1936 . McKibbin has argued that 'British films were rather disliked' up to the late $1930 \mathrm{~s} .{ }^{65}$ Certainly there was disregard for more 'popular' cinema amongst London critics. Yet the evidence of the exhibition lists of leading London and provincial cinemas listed in Kine Weekly suggests that British films were on average as popular as American ones. ${ }^{66}$

Of these British films, a 1973 analysis suggested that between 1929 and 1939 about 1.5 per cent of them were sports films. ${ }^{67}$ This was an under-estimate, since a large number of films in other categories, such as crime, comedy, musicals or adventure films, also dealt in passing with various British sports, or gambling on them in the form of racing sweepstakes or football pools. ${ }^{68}$ More than half of sports films had a racing or betting focus, although the quality of them in film critics' eyes was often poor.

Research carried out on audience preferences in the 1930s does not suggest that these British sporting films were particularly popular in comparison with other genres - films of plays or books, musicals and dance films, epics, historical and adventure films. Mass Observation in Bolton, for example, found musical romance, drama and tragedy, history and crime the most popular, with male youths being particular devotees of crime films. ${ }^{69}$ However we need to be careful in assessing the reliability of this data. Given that the bulk of films were on non-sporting themes it is possible that the questions asked by contemporary interviewers or recent oral historians may have obscured more favourable working-class responses. Women or middle-class interviewers were statistically less likely to be interested in popular sports, and Mass Observation interviewers had manifest difficulties in understanding the languages of popular culture in other contexts. ${ }^{70}$ In recent years more women than men have been interviewed about their recollections, and interwar sport was a more masculine interest.

Textual analysis of British films shows how racing was visually represented, imagined and received. Films had to appeal to the needs, wants and aspirations of the audience, and their skillfully-manipulated images showed British filmmakers' attitudes to the way they thought British society perceived the culture of racing and betting. Certainly Elstree producers were 'carefully and successfully evaluating the kinds of films the public wanted to see'. ${ }^{71}$ The success and popularity of some of these films suggest that they can provide an insight into the way ordinary people thought about racing.

The cultural meanings underlying these films are complex, subtle and difficult, not least since in films entertainment, ideology and audience came together. A unitary reading is impossible, and they indicate unresolved dualities and concealed conflicts in the thinking of authors, producers and audiences. All 
played a role in the social construction of meaning. They provide clues to tensions, contradictions and resistances in people's thinking about racing and betting. More generally they defined, mythicised and disseminated attitudes. Some were made to appeal to the working classes, the poor and unemployed through their often realistic elements and settings, their familiar atmosphere and social commentary and concerns, although many of the scenes are broad caricatures. In some of these films the working classes could see working-class environments, characters and conditions, including 'cops' and costermongers, bookmakers and betting, touts and tipsters.

But others preferred to enjoy racing through escapism, comedy, fantasy and wish-fulfilment, winning a big bet, living in a country house and having one's horse winning the Derby, and the audience response to such escapist films, emphasing tradition and social decorum, was particularly positive. This variety of needs was met by a relatively diverse film culture, part of an ideological process of shaping people's thoughts on racing, class, gender and culture. Racing films were capable of being read by audiences in a variety of ways, validating the interests and concerns of women as well as men, rational punters as well as those relying on luck, middle- as well as working-class audiences. ${ }^{72}$

Many films portrayed racing as a suitable theme for comedy. Film audiences always enjoyed 'humour'. In Up for the Derby (1933) comedian Sydney Howard played a punter who was lucky enough to pick out winning horses from a paper with an infallible pin, but unlucky enough to always find a dishonest bookmaker to place his bet. Finally broke, he became a stable lad, bought a brokendown horse for fifty shillings and trained it in the back garden of his Downs cottage, hiding it inside when he was pursued by brokers' men. The horse, of course, finally became a Derby winner.

The fast-talking Cockney Max Miller's Educated Evans (1936) portrayed its protagonist as a horse-racing tipster, friendly with the nouveaux riche, who becomes a trainer and eventually gets a fortune by backing the wrong horse. It suggested the unreliability of tipsters, and was hugely popular, especially in southern England. Funny and fast-moving, it grossed four times its costs, and was described by one London letter writer to Film Weekly as 'amusing, human and plausible'. ${ }^{73}$ In a sequel, Thank Evans (1938), the tipster has a long losing streak, gets involved with a crooked trainer, and makes money by persuading one of the trainer's unwitting owners to change his horse's dishonest jockey for a 'straight' one before the big race. In the North the leading box-office attraction was singer-comedian George Formby, a former professional jockey famous for cheap, profitable, social-satirical comic films, their popularity enhanced by his 
risqué, slightly smutty songs. ${ }^{74}$ His first film, in 1915, was a horse-racing drama, By the Shortest of Heads. In Come on George (1939), filmed at the peak of his popularity, he goes on the run after being falsely accused of theft, and shares a horsebox with a hitherto unmanageable racehorse whom he calms. So he is hired as stableboy/jockey to look after the horse and ride him in the big race. Unfortunately he loses his nerve, but is cured by a psychoanalyst and rides the horse to victory, outwitting a stock gang of crooks in the process.

Films were part of a culture of hope and consolation, often portraying cheerfully optimistic characters who craved good luck. Unsurprisingly, many such escapist films featured betting on horses. A successful bet meant happier times and circumstances. It built confidence, provided fortune and wealth. For the audience it anticipated an improvement in their economic circumstances. In most racing films closure was achieved when the horse finally won the big race, fortunes were recouped, the hero's merits were recognised and he got the girl, or the girl got the boy. In Two on a Doorstep (1936) a girl has a similar phone number to a bookmaker and begins to take some of the bets, setting up her own betting agency. She takes a big bet on a favourite and finds she owes more than she can pay, but recoups her fortunes by winning at a greyhound stadium. In Thoroughbred (1931) a racehorse trainer is suffering from amnesia, his success is disappearing, and as a result his girlfriend is going to have to marry the disagreeable son of her guardian. A racing accident restores the trainer's memory and he is revealed to be a man of considerable means.

An alternative way in which racing films helped deal with people's economic difficulties, impoverishment or decline in status was through plots which implied that wealth bred unhappiness. Purchasers of sweepstakes dreamt of winning and an upward shift in status. Given the long odds, they were almost certain to lose. Films helped them accept that, by suggesting that sudden riches could bring mixed blessings or cause social and cultural embarrassment. In Spring Handicap (1937), for example, a miner inherits a legacy and enters the racing world, and is equally unsuccessful at betting, bookmaking, tipping and owning before his wife brings him to his senses. In Sporting Love (1936) a couple attempt to cure their financial difficulties by running a horse in the Derby. It ends in disaster and further debt before they finally escape. The underlying message of such films was that if you didn't win the bet or the race, or even find well-paid work, it didn't matter. Success, wealth, status and power had their problems; you were better off even with hardship, pain and poverty. Envy and frustration were a waste of time. Watching such films may have helped diminish radicalism and disruption and contributed to the Conservative dominance of the 1930s. 
Attitudes to betting were usually positive. Several films gently mocked the anti-gambling group, or hinted that their attitude was hypocritical. In Don't Rush $M e$ (1936) two apparent anti-gambling zealots get themselves deeply involved in greyhound racing. In The Sport of Kings (1931) two racing toffs wager that they can get the puritanical anti-betting crank Amos Purdue JP to make a bet within a week. Purdue is soon not only betting on a grand scale, but turns bookmaker to recoup his losses. The presentation of bookmakers varied. Sometimes they are fairly sympathetically presented, indicating that even censors accepted betting as part of the social fabric. In Be Careful Mr Smith (1935) the eponymous hero, a retired clergyman, buys a bookmaking business to escape his nagging wife. In the 1938 comedy musical On Velvet the Cockney bookmaker and a Jewish punter have enormous losses but recover their fortunes with a television company.

Much more negatively, in Easy Money (1934) the two bookmakers are the villains of the comic piece, shady blackmailers whose evil is foiled by their more honest clerk. In the eerie 1933 film Eyes of Fate the shifty bookmaker bullies his wife, finds tomorrow's newspaper and wins a fortune at the races, before eventually reading of his own forthcoming death. In Trouble Brewing (1939) George Formby wins a bet but is paid with counterfeit money by the bookmaking gang.

News features in the racing press were sometimes recycled in fictional form. The doping or otherwise nobbling of horses, and the difficulty of identifying who was to blame, was one good example. In one of the first racing news films, P.C. Josser (1930), a policeman kicked out of the force redeems his reputation, aided by a trainer jailed for doping, by catching the real dopers. In Don't be a Dummy (1935), a racehorse owner and jockey are wrongly warned off for doping, but catch the crooks who framed them. In Dandy Dick(1935) a country vicar bets on a horse to raise money for his church spire, but has to clear himself of a doping charge before getting his winnings. The suggestion that horses might ever be pulled is challenged in The Calendar (1931), based on an Edgar Wallace stageplay, where an ex-convict butler helps a bankrupt horse owner prove he did not deliberately lose a race. Here, as in the case of positive images of bookmakers, racing films sometimes fail to follow conventional 'respectable' narratives about expected social roles, and can be highly subversive of predictable ideologies.

The increased wish of Americans to own the Grand National winner provides a useful vehicle for rounding off Luck of the Irish (1935), in which a financially struggling Irish gentry owner whose estates are mortgaged hopes to win the Grand National. Though his horse comes first, ridden by his amateur rider son, it is disqualified. His fortunes are saved only when a rich American buys his horse at a generous price. 
What is also interesting is what films did not show about racing, although it should be noted how censorship practices also contributed to presentation. Filmmakers were always careful, for example, never to suggest that street bookmaking often relied on complicity between bookmakers and the police. The British Board of Film Censors was quite clear that 'in this country we do not allow our police to be shown on the screen as ... accepting bribes from criminals' ${ }^{75}$ Films generally reflected conservative approval of the status quo, social stability and cohesiveness. In racing films only occasional trainers could be crooked, bookmakers dishonest or horses doped. This view that racing was generally 'all-square' but had its 'flotsam and jetsam' was the dominant image. The upper classes were sometimes lampooned and their pretensions exposed, yet were somehow usually 'straight' in their racing. Crooks in racing films were almost always working-class.

The quota system also created large numbers of one- or two-reeler British 'shorts'. One producer, N. R. Newman (established in 1929), specialised in horse-racing subjects. One example was his annual series called Derby Secrets, another his Gordon Richards. Although most 'shorts' were made by professional actors, photogenic Steve Donoghue's popularity enabled him to star in six short two-reel movies made at Islington Studios between 1925 and the 1930s. These linked romance and the turf to attract a female audience, coupled with stock criminal ingredients for the males, in a style reminiscent of Nat Gould or Edgar Wallace. Another, the first of these, Riding for a King (1925), starred Steve as a jockey who was the secret admirer of a beautiful married girl to whom he had given riding lessons. He had accepted the ride for the Lincoln Handicap on a horse owned by her jealous husband. The film's premiere, at the Tivoli theatre, drew a wide range of racing personalities, and Donoghue's acting was received with some praise. In 1937 he appeared in Wings of the Morning, which told the story of a Romany queen who owned a brown racehorse, secretly trained in Ireland, which won the Derby at 100-1.

Stage drama also drew on racing, featuring stock bookmakers as often as racing itself. Farces or comedies dominated. In the farce Sporting Love two owners of a bankrupt racing stable tried to kidnap their mortgaged prize horse. The classic Me and My Girl was probably the most successful theatre comedy of the period, starring veteran stage comic Lupino Lane as bookie Bill Snibson. ${ }^{76}$ It built on an earlier Lane stage success, a racing comedy called Twenty to One, in which the bookie joined the Anti-Gambling League, whose attitudes here again were largely ridiculed. In Me and My Girl the bookie is portrayed very positively. Lane inherits a title, and faces snobbery and numerous other class difficulties, before humanising the values and attitudes of his stereotypically portrayed aristocratic 
relatives more closely to those of working folk. Lane played the role over five thousand times, while it was broadcast on BBC radio in January 1938 and on $\mathrm{BBC}$ television at a special performance in front of King George VI and Queen Elizabeth. In The Naughty Age, later filmed as Strictly Illegal (1934), a street bookie wrongly thinks he has killed a policeman. On the run, he poses as a clergyman, is invited to be a country house guest and prevents a jewel theft. What both these latter plays showed, within an overall context of acceptance of the status quo, was the interdependence of classes, and people's ability to take on role impersonations.

Racing's widespread popularity meant that many fictional books with cultural representations of racing reached the reading public. A large section of the population revelled in romances with racing backgrounds. The public perception that racing was dishonest, coupled with the attractions of the crime novel, a popular interwar genre, provided novelists as diverse as Edgar Wallace, who knew his racing, and Enid Blyton, who did not know hers, with racing themes. Titles like Easy Money: The Amazing Adventures of Tom Denton, the Raffles of the Turf, or The TurfCrook, convey the sense of this literature. There were even specialist racing imprints. By mixing crime, romance and the turf, the Hornsea Journal Printing Works had published 262 'Racing Novels' by 1938, from small beginnings in around 1927. The Aldine Press began publishing its 'Aldine Racing Novels' in the early 1920s. Many such novels were potboilers, written by people with limited knowledge of racing. Graham Greene's 1938 novel, Brighton Rock, with its focus on the violent criminality of racecourse gangs, relied for its background on contemporary newspaper reports. Some authors specialised in racing fiction. Fairfax-Blakeborough occasionally attempted this, presenting 'real live people' and having 'far more intimate and accurate knowledge of racing and its governance' than the leading figure, Nat Gould. ${ }^{77}$

Gould was a Manchester man who had raced in Australia before returning to England and writing novels and plays with racing themes. ${ }^{78}$ His books sold at prices ranging from $6 s$ to the more popular $6 d$. He was hugely popular in Britain and the Empire, and his pre-First World War total book sales, well over eight million, had outstripped all other living writers. His books continued to be popular after his death in 1919, with reissues of his novels right through the period, sometimes in syndicated episodic form in the regional press. In 1920, for example, The Man from Newmarket, about 'life behind the scenes on the Turf', was serialised. ${ }^{79}$ His stories appealed to both women and men, and adopted a highly successful albeit relatively formulaic approach. The heroes of his books are often fairly wealthy, honourable, 'manly', self-made sportsmen, 
who own racehorses which are inevitably finally successful in a major race after some form of adverse experience. The hero often falls in love with and finally marries a society beauty, after solving some mystery committed by a stock villain often described in racist and class-biased ways. The settings are dominated by country estates, Ascot, Newmarket and Australia.

In The Roarer, for example, the hero, wealthy millionaire Wilton West, inherits his Sherwood estates after the unsolved murder of his father, a marked knife having been found nearby. He takes two of his horses to Australia with the intention of running them in the Melbourne Cup, and is accompanied by friends, including the mildly scandalous but attractive widow Lady Florence Evershed, who provides the sexual and romantic subplot. One of his horses, Viking, turns roarer, and is thought to have little chance of winning. The murderer of West's father is revealed as an Australian bookmaker, Baptiste Leon, the stock description of whom fulfils almost all the British racial, physiological and social prejudices of the early twentieth century. He is a 'bad lot', whose family were 'Spaniards of the lower class', with 'dark snake-like eyes' and dark, swarthy complexions. He owns the murder knife. Leon takes West's bets and is broken when Viking wins the Melbourne Cup. He attempts to default and escape, but is killed in a knife fight with a former accomplice Corti, who has learned the error of his ways. West returns to England, marries Lady Florence and wins the Ascot Gold Cup with Viking.

Book sales remained buoyant during the interwar years. At the upper end of the cultural continuum the sales of racing paintings also continued to find a market, although with more emphasis on steeplechasing than before the First World War, reflecting its increasing respectability and popularity amongst many of the nouveaux riches. Eric Fraser's Derby Day (1926) or Cermansky's Frith's Derby Day Modernised (1931) showed the continued popularity of racing realism in painting, and followed the earlier traditions of representing racemeetings found in nineteenth-century magazines like the Illustrated London News, while Sir John Lavery's The Jockeys' Dressing Room at Ascot (1923) shows a more 'modern', intimate, inside view of the sport. By contrast demand for racing prints diminished, perhaps with the decline in wealth of the land-owning group that had been major patrons of the genre. ${ }^{80}$

\section{Conclusion}

Despite the complex variety of regional and local experience, racing had become increasingly respectable by 1939 , with its best-known races well 
integrated into cultural life and accorded high status. The BBC had 'brought the racecourse into every home' ${ }^{81}$ The varied representations of racing demonstrate that racing provided high levels of indirect employment opportunities. The number of those employed in the mass media to produce such material, at all levels from journalists and editors, directors and tea boys, to cameramen and commentators, must have been considerable.

More importantly this chapter provides an alternative insight into the fundamental character of British society between the wars by revealing that racing and betting images had become all-pervasive throughout Britain, part of a cohesive common culture, a shared frame of reference characterised by social inclusiveness and accessibility. Racing's representation in the national and sporting press, the $\mathrm{BBC}$, the cinema, fiction and non-fiction, and other forms of mass media, together provided a cumulative cultural validation of the sport in British society.

The commonality of racing culture portrayed in the mass media helped both to define the collective identity of the British and to shift their interests more towards frank enjoyment of leisure. The period saw a substantive move towards the affluent consumption of sporting experience and betting, a view which the $\mathrm{BBC}$ was slow to embrace. This shared interest united individuals of otherwise widely divergent tastes in an increasingly diverse and complex culture. To individuals from all social classes and regions, the culture of the period was more likely to be reflected in films like Come on George, the racing tips and results in the press, or the wireless commentary on the National, than it was in the poems of W. H. Auden or the novels of Virginia Woolf.

At the same time however the picture of racing these cultural artefacts presented was ambiguous. Some images of racing were positive: honest owners or bookmakers, lucky punters, successful trainers and owners, exciting races. Others painted a more negative picture: of criminality, dishonesty or addiction to betting. It was the latter upon which the anti-gamblers fixed. The following chapter explores their beliefs, work and anti-gambling activities.

\section{Notes}

1 For an analysis of the importance of the notion of 'cultural citizenship' in linking the public and the private, consumers and producers, subjectivity and objectivity, pleasure and politics, see J. Hermes, 'Gender and media studies: no woman, no cry', in John Corner, Philip Schlesinger and Roger Silverstone (eds), International handbook of media research (London: Routledge, 1997), p. 88.

2 See David Morley, Television, audiences and cultural studies (London: Routledge, 1992). 
3 J. B. Booth, Sporting Times: the Pink Un world (London: Werner Laurie, 1938), p. 238.

4 For the broader theoretical background to this field see David Rowe, Sport, culture and the media (Buckingham: Open University Press, 1999).

5 A useful source is Arthur J. Sarl, Horses, jockeys and crooks: reminiscences of thirty years' racing (London: Hutchinson, 1935), ch. 32, 'Gentlemen of the press'. See also Norman Pegg, Focus on racing (London: Robert Hale, 1963), and Eric Rickman, On and off the racecourse (London: Routledge, 1937).

6 Sporting Life, 23.2.1924.

7 Pegg, Focus on racing, p. 10.

8 Quintin Gilbey, Fun was my living (London: Hutchinson, 1970), p. 200.

9 Meyrick Good, The lure of the turf(London: Odhams Press, 1957), p. 207.

10 Foreword to George Hamlyn, My sixty years in the ring: a racing and gambling autobiography (Hungerford: Sporting Garland Press, 1994).

11 Eric Rickman, Come racing with me (London: Chatto and Windus, 1951), pp. 4, 9; Noel Fairfax-Blakeborough (ed.), J. F-B: the memoirs of Jack Fairfax-Blakeborough (London: J. A. Allen, 1978), p. 71; Sarl, Horses, jockeys and crooks, p. 274, and ch. 32, passim.

12 M. Gilbert, Winston S. Churchill, Vol. V, 1922-1939(London: Heinemann, 1976), p. 731, quoted by David Dixon, From prohibition to regulation: bookmaking, antigambling and the law (Oxford: Clarendon Press, 1991), p. 285.

13 Peter O'Sullevan, Calling the horses: a racing autobiography (London: Hodder and Stoughton, 1994), p. 13.

14 Leonard Jayne, Pony racing, including the story of Northolt Park (London: Hutchinson, n.d.), p. 17.

15 Competition between the three leading racing papers, the Sportsman, the Sporting Life, and the Sporting Chronicle, to return 'official starting prices' was only resolved in the 1920s. See J. M. Scott, Extel 100: The centenary history of the Exchange Telegraph Company (London: Ernest Benn, 1972), p. 72.

161923 Select Committee on Betting Duty, Minutes of Evidence QQ6233-39 (Gulland).

17 Memorative biography, Bloodstock breeders' review, 1931, p. 116.

18 Gordon Richards's foreword to Quintin Gilbey, Champions all: Steve to Lester (London: Hutchinson, 1971).

19 D. L. LeMahieu, A culture for democracy: mass communication and the cultivated mind in Britain between the wars (Oxford: Clarendon Press, 1988), pp. 56-79.

20 The demand for racing material was such that a number of tipsters were also able to publish books. 'The Scout' (Cyril Luckman), The Scout's guide to racing 1937 (London: Daily Express, 1937), for example, provided 512 pages of reference material for racing fans.

211923 Select Committee, QQ6380-6 (Gulland).

22 For more detailed discussion of the influence of tipsters on betting behaviour see James R. Hall, 'The racing media in Britain from Prince Charlie to Zafonic: some neglected perspectives', MA diss., University of Lancaster, 1993, ch. 3. 
23 Michael Seth-Smith and Roger Mortimer, Derby 200: the official story of the Blue Riband of the turf(Enfield: Guiness Superlatives, 1979), p. 48.

24 Yorkshire Evening Press, 22-25.8.1932.

25 M. Seth-Smith et al., The history of steeplechasing (London: Joseph, 1966), p. 126.

26 The Times, 3.6.1922; ibid., 20.6.1919.

27 Yorkshire Herald, 28.8.1937; Liverpool Echo, 24.3.1938.

28 Although Fairfax-Blakeborough was a prolific writer between the 1930s and the 1960s, he often recycled the same stories. Good examples of his approach are Jack Fairfax-Blakeborough, Paddock personalities: being thirty years of turf memories (London: Hutchinson and Co., 1935), and Jack Fairfax-Blakeborough, The analysis of the turf (London: Philip Allan, 1927).

29 See Noel Fairfax-Blakeborough (ed.), J. F.-B: the memoirs of Jack FairfaxBlakeborough (London: J. A. Allen, 1978).

30 See Richard Marsh, A trainer to two kings (London: Cassell, 1925); John Porter, John Porter of Kingsclere (London: Grant Richards, 1919); E. M. Humphris, The life of Mathew Dawson (London: Witherby, 1928); George Lambton, Men and horses I have known (London: Thornton Butterworth, 1924); Alfred E. T. Watson, A great year: Lord Glanley's horses (London: Longmans Green, 1921); R. C. Lyle, Brown Jack (London: Putnam, 1934).

31 For example, B. R. M. Darwin, John Gully and his Times (London: Cassell, 1935); E. M. Humphris, The life of Fred Archer (London: Hutchinson, 1923); E. M. Humphris, The life of Matthew Dawson (London: Witherby, 1930); T. H. Bird, Admiral Rous and the English turf 1795-1877 (London: Putnam, 1939), or E. E. Dorling, Epsom and the Dorlings (London: Stanley Paul, 1939).

32 For example, D. H. Munroe, The Grand National, 1839-1931 (London: Heinemann, 1931); T. H. Bird, A hundred Grand Nationals (London: Country Life, 1937); A. Macey, The romance of the Derby stakes (London: Hutchinson, 1930); J. S. Fletcher, The history of the St. Leger stakes, 1776-1926 (London: Hutchinson, 1927).

33 For example C. M. Prior, The history of the Racing Calendar and Stud Book from their inception in the eighteenth century (London: Sporting Life, 1926); T. H. Browne, History of the English turf 1904-1930 (London: Virtue, 1931).

34 The Times, 1.6.1922.

35 Sian Nicholas, 'All the news that's fit to broadcast: the popular press versus the BBC, 1922-45', in Peter Catterall et al. (eds), Northcliffe's legacy: aspects of the British popular press 1896-1996 (Basingstoke: Macmillan, 2000), p. 127.

36 The following paragraphs are based largely on R. Glendenning, 'Race broadcasting', in Ernest Bland (ed.), Flat racing since 1900 (London: Andrew Dakers, 1950), pp. 224-30.

37 For Allison see Dave Russell, Football and the English (Preston: Cicerone Press, 1997), pp. 106-7. Good, The lure of the tur, f gives details of Good's racing experiences. Another popular commentator was R. C. Lyle, the Times racing correspondent.

38 O'Sullevan, Calling the horses, p. 9. Good was paid 100 guineas for the commentary. 
39 The Times, 30.5.1933.

40 Gilbey, Fun was my living, p. 160.

41 The Times, 26.3.1938.

42 Michael Seth-Smith, Steve: the life and times of Steve Donoghue (London: Faber and Faber, 1974), pp. 225-6.

43 Bloodstock breeders' review, (1931), p. 26.

44 Daily Telegraph, 3.6.1931.

45 The Times, 27.1.1938.

46 Jayne, Pony racing, p. 88.

47 The Times, 2.6.1938.

48 Rachael Low, Films of comment and persuasion in the 1930s (London: Allan and Unwin, 1979), pp. 53-6.

49 Edward Abelson and John Tyrrel, The Breedon book of horseracing records (Derby: Breedon Books, 1993), p. 245.

50 Strand Magazine (1896) quoted in Seth-Smith and Mortimer, Derby 200, p. 38.

51 The Times, 2.6.1921.

52 The Times, 29.3.1938.

53 Quoted in Low, Films of comment, p. 16.

54 Liverpool Daily Post, 30.3.1935.

55 Liverpool Echo, 21-24.3.1922.

56 Yorkshire Herald, 25.8.1938.

57 Seabiscuit supposedly got more column inches in 1938 in the USA than any other news figure. See Laura Hillenbrand, Seabiscuit: three men and a racehorse (London: Fourth Estate, 2002), p. xi.

58 Liverpool Echo, 22.3.1938.

59 1932/3 Royal Commission on Lotteries and Betting, para. 218.

60 Sporting Chronicle, Racing up-to-date: a complete record of flat racing (Manchester: Sporting Chronicle, 1938), p. 172.

61 S. Theodore Felstead, Racing romance (London: Werner Laurie, 1949), pp. 79-80.

62 Hartlepool Daily Mail, 30.7.1936.

63 Reviewed in the Cleveland Standard, 5.8.1939.

64 Stephen C. Shafer, British popular films 1929-1939: the cinema of reassurance (London: Routledge, 1997), pp. 1-2. See also Marcia Landy, British genres: cinema and society 1930-1960 (Princeton, NJ: Princeton University Press, 1991) and Jeffrey Richards (ed.), The unknown 1930s: an alternative history of the British cinema 1929-1939(London: B. Tauris, 1998).

65 Ross McKibbin, Classes and cultures: England 1918-1951 (Oxford: Oxford University Press, 1998), p. 456.

66 John Sedgwick, 'Cinema-going preferences in Britain in the 1930s', in Richards (ed.), Unknown 1930s.

67 Dennis Gifford, The British film catalogue, 1875-1970: a guide to entertainment films (Newton Abbott: David and Charles, 1973); John Walker, Halliwell's film and video guide (London: HarperCollins, 1998). The following sections on film draw partly on the summaries of films given here. 
68 Several films, including Lancashire Luck (1937), were based round the potential problems a football pools win could cause. The Last Coupon (1932) and Penny Paradise (1938) both show how a family was adversely affected by an expected win before finding the coupon had not been posted.

69 Jeffrey Richards and D. Sheridan (eds), Mass observation at the movies (London: 1987), p. 34.

70 See for example Gary Cross (ed.), Worktowners at Blackpool (London: Routledge, 1990).

71 Shafer, British popular films, p. 23.

72 For the notion of 'active audiences' see John Fiske, Television culture (London: Methuen, 1987), and John Fiske, Reading the popular (London: Unwin Hyman, 1990).

73 Film Weekly, 3.4.1937; quoted in Shafer, British popular films, p. 44.

74 For his popularity see Jeffrey Richards, Age of the dream palace: cinema and society in Britain 1930-1939 (London: Routledge, 1984), p. 160; McKibbin, Classes and cultures, p. 437.

75 Annual Report of the British Board of Film Censors, 1933, quoted in Shafer, British popular films.

76 It was later filmed as The Lambeth Walk.

77 Fairfax-Blakeborough issued his first six racing romances in 1933. See 'Some Good racing novels', Bloodstock breeders' review, 1933, pp. 160-1.

78 His first major work was Nat Gould, On and off the turf in Australia (London: Routledge, 1895).

79 Cleveland Standard, 21.8.1920.

80 Charles Lane, British racing prints 1700-1940 (London: Sportsman's Press, 1990), p. 61.

81 C. R. Acton, Silk and spur (London: Richards, 1935), p. x. 